\title{
Analysis of Influences of Waste - Dumping Sites on the Quality of Water
}

\author{
Adetoro A. E. ${ }^{1}$ and Adams J. O. ${ }^{2}$ \\ ${ }^{1,2}$ Civil Engineering Department, the Federal Polytechnic, Ado - Ekiti, Nigeria.
}

\begin{abstract}
Leachates from waste dumping sites always find its way into surface and underground water through percolation and surface run-off whenever there is rainfall - This is due to problems of improper waste disposal and management especially in developing countries. Thus, influences of these leachates on water qualities of the study area were analyzed. Water samples were taken from stream and well water around the waste dumping sites in the study area and necessary laboratory tests were conducted on them. The tests results portrayed the evidence of high water pollution / contamination due to the leachates. Conclusively, both the stream and well water are not fit for consumption and unsuitable for Civil Engineering works due to presence of $E$-coli bacteria, high turbidity and concentration of some elements and compounds. These show that waste - dumping sites have great negative influences on the water quality of the study area and any part of the World with this kind of situation.
\end{abstract}

Keywords: Consumption, Developing countries, Leachates, Waste disposal and management, Waste dumping site, Nigeria.

\section{Introduction}

Proper waste disposal and management have been problems of developing countries like Nigeria from very long past. Wastes are usually deposited into places or sites like surface water (i.e. flowing river, lake, dam etc) and land (i.e. abandoned or undeveloped plot of land in a developed area, uncompleted building or structure etc). Whenever there is rainfall, leachates from these waste dumping sites usually find its way into surface and underground water through percolation and surface run-off. Thus, surface and underground water (which serve as means of livelihood in developing countries) are exposed to immeasurable danger. The results are always all sorts of water related and communicable diseases to the end users. Summarily, the surface and underground water are contaminated through the leachates (i.e. organic and inorganic waste constituents) [1], [2], [3].

The above explained phenomenon is very common in many developing countries especially Nigeria where there is high population growth due to industrialization and urbanisation. The past research works of [1], [2], [3], [4], [5], [6] and others looked into effects of waste dumping sites on the water quality (ies) especially in developing countries where inappropriate waste disposal and management is rampant.

Nevertheless, the aim(s) of this piece of research work is to analyse the influences of waste dumping sites on the quality of water of the study area. This will help in having reliable scientific facts or knowledge about the characteristics and quality (ies) of water available in the study area and that part or whole of Southwestern Nigeria.

\section{Materials And Methods}

2.1 Study Area: The study area is Erifun, a suburb of Ado-Ekiti Metropolis that is currently undergoing rapid urbanisation. While Ado-Ekiti is capital of Ekiti State situated in Southwestern part of Nigeria (Fig.1). Erifun is located on latitude $7.607^{\circ} \mathrm{N}$ and longitude $5.289^{\circ} \mathrm{E}$. Its landscape consists of out cropping done rocks situated within tropical climate of Nigeria and is $384 \mathrm{~m}$ above sea level. 


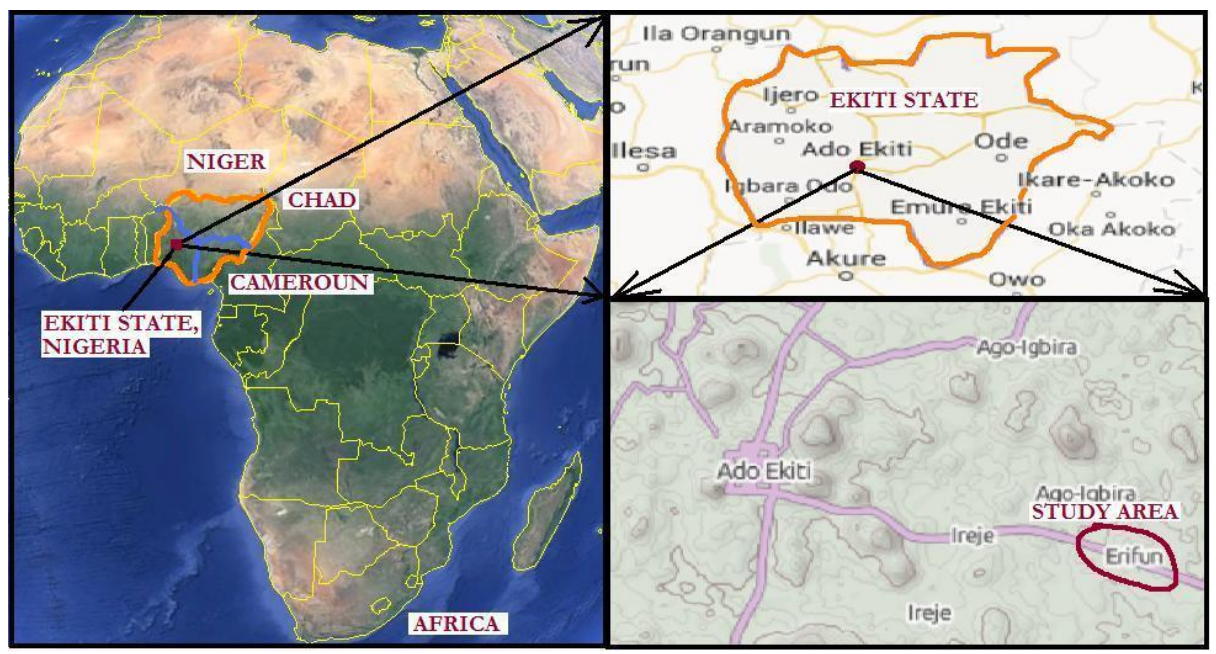

Figure 1: Location of the Study area - Erifun (after Reference [7])

Geologically, Ekiti State (where the study area is situated) is underlain by metamorphic rocks of the Precambrian basement complex of Southwestern part of Nigeria, the great majority of which are very ancient in age. These basement complex rocks show great variations in grain size and in mineral composition. The rocks are quartz gneisses and schists consisting essentially of quartz with small amounts of white mizageous minerals. In grain size and structure, the rocks vary from very coarse-grained pegmatite to medium-grained gneisses. The rocks are strongly foliated and occur as outcrops [1], [8].

The soils derived from the basement complex rock are mostly well drained, having medium to coarse in texture. The geological nature of the study area and its increased urbanisation make it more vulnerable and of public health concern when it comes to water quality [1], [8].

2.2 Sample Collection and Analysis: Water samples were collected at random from the upstream and downstream of the streams and wells in Erifun, a suburb of Ado-Ekiti Metropolis during the day before sun set using sterilized plastic containers of two litres capacity. The stoppers of the collection containers were carefully removed and dipped into the river by holding it through the base. At about $0.3 \mathrm{~m}$ depth, their mouths were directed to the direction of flow (current) and when enough water had entered, they were brought out and stoppers replaced, while the temperature were determined immediately.

The sampling containers were properly labelled using different identification marks. The containers were properly rinsed with distilled water before used, immediately covered and on-site examinations were carried out. The samples were then brought to Water/Public Health Laboratory, Civil Engineering Department, The Federal Polytechnic, Ado-Ekiti for laboratory tests. All tests were conducted in accordance with [9] and [10] standard methods. All the necessary properties were established putting into consideration all relevant factors. The tests carried out on each of the selected samples are physical, chemical and bacteriological tests. The physical tests carried out are on appearance, colour, hardness, odour, temperature, turbidity and dissolved solids. The chemical tests carried out are on Potentials of Hydrogen (PH), contents of calcium, chloride, iron and magnesium, total alkalinity, nitrate, dissolved oxygen and phosphate levels. While the bacteriological tests carried out are on the excremental pollution and bacteria density of the water samples of the study area - Plate count (Agar) and Colony counter tests. The results were then compared with the World Health Organisation ([9] and [10]) water quality standard values.

\section{Results And Discussion}

Results of the tests of selected water samples are presented in Tables 1 to 3 .

Table 1: Summary of Physical test results on the water samples(Location: Erifun, a suburb of Ado - Ekiti Metropolis)

\begin{tabular}{|c|l|c|c|c|c|}
\hline \multirow{2}{*}{ S/NO. } & \multirow{2}{*}{ TESTS } & \multicolumn{3}{|c|}{ SOURCE } & $\begin{array}{c}\text { WHO WATER QUALITY STANDARD } \\
\text { VALUES (SOURCE : WHO, 2011) }\end{array}$ \\
\cline { 3 - 6 } & & UPSTREAM & DOWNSTREAM & WELL & PERMISSIBLE / TOLERABLE LIMIT \\
\hline 1 & Appearance & Turbid & Cloudy & Clear & Unobjectionable \\
\hline 2 & Temperature $\left({ }^{\circ} \mathrm{C}\right)$ & 23 & 21 & 20 & Cool temperature values \\
\hline 3 & Colour $(\mathrm{TCU})$ & 20 & 25 & 10 & $<15.0$ \\
\hline 4 & Turbidity $(\mathrm{NTU})$ & 50.2 & 35.5 & 9.2 & $<1.0$ \\
\hline 5 & Total Dissolved Solids $(\mathrm{mg} / \mathrm{l})$ & 62.5 & 64.79 & 75.4 & $<600$ \\
\hline 6 & Total Hardness $(\mathrm{mg} / \mathrm{l})$ & 180 & 180 & 60 & $500-1000$ \\
\hline 7 & Odour & Deep odour & Unpleasant odour & Faint Odour & Odourless \& Pleasant \\
\hline
\end{tabular}


From TABLE 1, it is observed that the Temperature values of the water samples varied between $20^{\circ} \mathrm{C}$ and $23^{\circ} \mathrm{C}$. These temperature values are within the permissible limits when compared with WHO standard values. In appearance, the water samples from the stream are not clear while the one from well is clear. The Colour values range between 10 and 25 TCU. Only the well water was within the permissible limits when compared with WHO standard values, the upstream and downstream water of the stream were not (i.e. 20 and $25 \mathrm{TCU})$. This shows that only the well water is fit for consumption. Change in impurity levels at different location is considered the reason for the changes in the colour values of the water samples.

The turbidity values of all the samples varied between 9.2-50.2 NTU. These values are higher than the tolerable or permissible WHO limits. There is also change in turbidity values due to impurity level (i.e. Upstream water sample has 50.2 NTU, Downstream water sample has $35.5 \mathrm{NTU}$ and the Well water sample has 9.2 NTU). Total Dissolved Solid values varied between $62.5 \mathrm{mg} / \mathrm{l}$ and $75.4 \mathrm{mg} / \mathrm{l}$. Though it is within the WHO limits, it is observed that the total dissolved solids increase in value with the length of river course with the well water having the highest total dissolved solid and the upstream water having the lowest. It implies that the stream water picks up substances (soluble and insoluble), which renders the water unfit for consumption.

The values of hardness obtained from the analysis of the water samples ranges from $60 \mathrm{mg} / 1$ to $180 \mathrm{mg} / 1$. The lowest value of the hardness is from the well water sample and the highest value from the stream water samples. Though these values of hardness are within recommended WHO limits, the result shows that the well water is the softest of all the water. The upstream water has deep odour. This is due to the effluents and wash off from rainfall of decaying waste deposits at the bank of the river. This odour becomes deeper and unpleasant at the downstream because of its high level of pollution. The well water has faint odour. This implies that the soil between the stream and well is unable to completely filter all the polluted substances out of the stream water before it reaches the well location. These results show that all the water is unpleasant and unacceptable in accordance with WHO standards.

Table 2: Summary of Chemical test results on the water samples(Location: Erifun, a suburb of Ado Ekiti Metropolis)

\begin{tabular}{|c|l|c|c|c|c|}
\hline \multirow{2}{*}{ S/NO. } & \multirow{2}{*}{ TESTS } & \multicolumn{3}{|c|}{ SOURCE } & $\begin{array}{c}\text { WHO WATER QUALITY STANDARD } \\
\text { VALUES (SOURCE : WHO, 2011) }\end{array}$ \\
\cline { 3 - 6 } & & UPSTREAM & DOWNSTREAM & WELL & PERMISSIBLE / TOLERABLE LIMIT \\
\hline 1 & $\mathrm{pH}$ & 7 & 7 & 5.5 & $6.5-8.5$ \\
\hline 2 & Calcium $(\mathrm{mg} / \mathrm{l})$ & 32.87 & 14.43 & 4.01 & $100-300$ \\
\hline 3 & Magnesium $(\mathrm{mg} / \mathrm{l})$ & 82 & 36 & 10 & $50-80$ \\
\hline 4 & Iron $(\mathrm{mg} / \mathrm{l})$ & 3.0 & 4.0 & 3.0 & $<0.30$ \\
\hline 5 & B.O.D & 4.5 & 3.6 & 1.2 & $0.01-1.0$ \\
\hline 6 & Nitrates $(\mathrm{mg} / \mathrm{l})$ & 0.2 & 0.2 & 0.2 & 50 \\
\hline 7 & Alkalinity $(\mathrm{mg} / \mathrm{l})$ & 630 & 730 & 900 & 600 \\
\hline 8 & Chloride $(\mathrm{mg} / \mathrm{l})$ & 652.28 & 751.54 & 999.69 & $200-300$ \\
\hline 9 & Dissolved Oxygen $(\mathrm{ppm})$ & 0.30 & 0.30 & 0.35 & Very high level not accepted \\
\hline 10 & Phosphate $(\mathrm{mg} / \mathrm{l})$ & 35 & 39.5 & 0 & 50 \\
\hline
\end{tabular}

From TABLE 2, it is observed that the $\mathrm{pH}$ values gotten from the tested water samples ranges from 5 to 7. The well water has $\mathrm{pH}$ of 5.5, which is below the WHO permissible limits and shows that it is acidic in nature, though the acid is weak. While the stream water has $\mathrm{pH}$ of 7, which is within the WHO permissible limits and shows that it is neutral in nature and fit for consumption. The Calcium and Magnesium contents range from $4.01 \mathrm{mg} / \mathrm{l}$ to $32.87 \mathrm{mg} / \mathrm{l}$ and $10 \mathrm{mg} / \mathrm{l}$ to $82 \mathrm{mg} / \mathrm{l}$, which are lower than the WHO limits. Though there is variation in their concentrations in all the water samples, it poses no hazard to them. The level of iron concentration obtained from the water samples ranges from $3.0 \mathrm{mg} / \mathrm{l}$ to $4.0 \mathrm{mg} / \mathrm{l}$, which is higher than the WHO allowable limit. This implies that the water is not fit / palatable for consumption.

Chloride ions concentration in the water samples ranges between $652.28 \mathrm{mg} / \mathrm{l}$ and $999.69 \mathrm{mg} / \mathrm{l}$, which are higher than the tolerable or permissible limit according to W.H.O standard limits. Thus, the presence of high chloride ion concentration in the water (i.e. both stream and well) causes taste, corrosion and renders them nonpalatable or unfit for consumption.

Phosphate concentration in the water samples ranges between $0 \mathrm{mg} / \mathrm{l}$ and $39.5 \mathrm{mg} / \mathrm{l}$, which are within the WHO limits. The dissolved oxygen content varies from $0.42 \mathrm{ppm}$ to $0.45 \mathrm{ppm}$, which is also acceptable. 
Table 3: Summary of Bacteriological test results on the water samples

\begin{tabular}{|c|c|c|c|c|l|l|}
\hline LOCATION & SOURCE & $\begin{array}{c}\text { COLIFORM } \\
\left(\text { C.F.U } \times 10^{5}\right.\end{array}$ & E - COLI & Colonies & $\begin{array}{l}\text { PLATE COUNT } \\
\text { REMARKS }\end{array}$ & $\begin{array}{l}\text { W.H.O BACTERIOLOGICAL STANDARD } \\
\text { VALUES (SOURCE : WHO, 2011) }\end{array}$ \\
\hline \multirow{2}{*}{$\begin{array}{c}\text { ABA - ERIFUN } \\
\text { AREA }\end{array}$} & UPSTREAM & 14 & Positive & 17 & Unsatisfactory & $\begin{array}{l}\text { 1. No Sample should contain E-Coli in } \\
\text { 100ml }\end{array}$ \\
\cline { 2 - 7 } & DOWNSTREAM & 18 & Positive & 12 & $\begin{array}{l}\text { 2. No sample should contain more than } 10 \\
\text { Coliform organism per } 100 \mathrm{ml} \\
\text { 3. Coliform organisms should not be } \\
\text { detected in100ml in any consecutive } \\
\text { samples }\end{array}$ \\
\cline { 2 - 7 } & WELL & 10 & Positive & 12 & Unsatisfactory \\
\hline
\end{tabular}

\section{NOTE}

E - COLI shows a sewage indicator of pollution and feacal organism originated from feaces of intensive parasite of man.

From TABLE 3, it is observed that all the bacteriological tests results showed that all the water samples are positive to E. coli and unsatisfactory. Thus, it is evident that the pollution or contamination of the sampled water is very high.

\section{Conclusion And Recommendation}

The tests results showed that the stream water is cool in temperature and not clear. It has visible colour and high turbidity, which reduces as the water flows downstream. It is soft (i.e. allowable hardness) with deep odour and allowable total dissolved solids which becomes deeper, unpleasant and increase in values downstream. Its $\mathrm{pH}$ values are neutral in scale, thus the water is fit for consumption. Its Chloride ions and Iron concentrations (contents) are very high and not within the allowable limits. This shows that the water has taste and corrosion tendencies, thus unfit for consumption. The calcium, dissolved oxygen and phosphate concentrations are within the allowable limits, thus pose no hazards to the water. Some of the alkalinity and magnesium concentrations are higher than the allowable limits. There is also presence of E - coli bacteria in large quantity (i.e. not satisfactory). This shows the evidence of water pollution.

While the tests results showed that the well water is cool in temperature and clear. It is colourless with high turbidity. It is softer than the stream water (i.e. allowable hardness) with faint odour and allowable total dissolved solids. Its $\mathrm{pH}$ values are acidic in scale though weak, thus the water is unfit for consumption. Its Chloride ions and Iron concentrations (contents) are very high and not within the allowable limits. This shows that the water has taste and corrosion tendencies, thus unfit for consumption. The calcium, dissolved oxygen, magnesium and phosphate concentrations are within the allowable limits, thus pose no hazards to the water. However, the alkalinity concentration is higher than the allowable limits. There is also presence of $\mathrm{E}-\mathrm{coli}$ bacteria in large quantity (i.e. not satisfactory). This shows the evidence of water pollution - presence of faecal organisms and leachates in the water.

Conclusively, both the stream and well water are not fit for consumption and unsuitable (to some degrees) for Civil Engineering works due to presence of E -coli bacteria, high turbidity and concentration of some elements and compounds. These show that waste - dumping sites have great negative influences on the water quality of Ado-ekiti metropolis and any part of the World with this kind of situation.

\section{References}

[1] W. O. Adebayo, Waste Generation Disposal and Management Techniques in an Urbanization Environment - A Case Study of AdoEkiti, Nigeria, Research Journal of Applied Science, 1(1), 2006, 155 - 160.

[2] E. O. Akudo, G. U. Ozulu, and L.C. Osogbue, Quality Assessment of Ground Water in Selected Waste Dumpsites Areas in Warri, Nigeria. Environmental Research Journal, 4(4), 2010, 281 - 285.

[3] B.A. Adelekan, and K.D. Abegunde, Heavy Metals Contamination of Soil and Groundwater at Automobile Mechanic Village in Ibadan, Nigeria, International Journal of Physical Science, 6(5), 2011, 1045 - 1058.

[4] O.O. Odukoya, T.A. Arowolo and O. Bamgbose, Effect of Solid Waste Landfill on Underground and Surface Water Quality at Ring Road, Ibadan, Nigeria, Global Journal of Environmental Science, 1(1), 2002, 45 - 52.

[5] K. Shamlar, S. Aravindan and S. Rajendran, Assessment of Groundwater Quality in Paravanar River Sub-Basin, Guddalore District, Tamil Nadu, India, Advances in Applied Science Research, 2(5), 2011, 92 - 103.

[6] S.P. Jeyapriya, and M.K. Saseetharan, Effect of Municipal Solid Waste on the Characteristic of Soil, Pollution Research Paper. 29(1), $201037-41$.

[7] Europa Technologies, Google Earth 2010, Available: http://earth.google.com/, 2014.

[8] F.A. Akintola, Geology and Geomorphology: Nigeria in maps. London, England: Hoder and Stoughton, 1982.

[9] World Health Organisation (WHO), WHO Guidelines for Drinking Water Quality (4 ${ }^{\text {th }}$ Ed.), Online, Available: http://www.who.int, 2014.

[10] World Health Organisation (WHO), WHO Guidelines for Drinking Water Quality (2 ${ }^{\text {nd }}$ Ed.), Online, Available: http://www.who.int, 1996. 